\title{
Correction to: 3-Triethylammonium propane sulfonate ionic liquids for Nafion-based composite membranes for PEM fuel cells
}

Letícia Zanchet ${ }^{1}$, Letícia Guerreiro da Trindade ${ }^{2}$, William Bariviera ${ }^{1}$, Katiúscia M. Nobre Borba ${ }^{1}$, Rapher Donizete Moreira Santos ${ }^{3}$, Valdecir Antonio Paganin ${ }^{3}$, Cristiane Pontes de Oliveira ${ }^{1}$, Edson Antonio Ticianelli ${ }^{3}$, Emilse Maria Agostini Martini ${ }^{1, \star}$, and Michèle Oberson de Souza ${ }^{1, \star}$

${ }^{1}$ LRC - Institute of Chemistry, Universidade Federal do Rio Grande do Sul, P.O. Box 15003, Porto Alegre, RS 91501-970, Brazil

${ }^{2}$ Department of Chemistry, Universidade Estadual Paulista-Unesp, P.O. Box 473, Bauru, SP 17033-360, Brazil

${ }^{3}$ São Carlos Institute of Chemistry, University of São Paulo, P.O. Box 780, São Carlos, SP 13560-970, Brazil

Published online:

29 May 2020

(C) Springer Science+Business

Media, LLC, part of Springer

Nature 2020
Correction to: Mater Sci (2020) 55:6928-6941 https://doi.org/10.1007/s10853-020-04454-4

After the manuscript was revised following peer review, an error was introduced in the conductivity data reported in Table 3. Adding the standard values (SD) of the original values, which were correct, we made an error about the unit used for the membrane thickness.

Consequently, all the published conductivity values and their standard deviation (SD) need to be multiplied by $10^{-1}$.

Below is Table 3 with the corrected values as well as their SD.

The original article can be found online at https:/ / doi.org/10.1007/s10853-020-04454-4.

Address correspondence to E-mail: emilse.martini@ufrgs.br; michele.souza@ufrgs.br 
Table 3 Ionic conductivity of NTHS2.5, NTHS5, NTHS10, NTCF2.5, NTCF5, NTCF10, NTCF10, NTCF2.5, NTBF5, NTBF10 and ND2020 composite membranes at $25{ }^{\circ} \mathrm{C} / 100 \% \mathrm{RH}$ (relative humidity) and $80{ }^{\circ} \mathrm{C} / 60 \% \mathrm{RH}$

\begin{tabular}{lllll}
\hline Sample & \multicolumn{3}{l}{ Ionic conductivity $\left(\mathrm{S} \mathrm{cm}^{-1}\right)$} \\
\cline { 2 - 5 } & $25^{\circ} \mathrm{C} / 100 \% \mathrm{RH}$ & $\mathrm{SD}$ & $80{ }^{\circ} \mathrm{C} / 60 \% \mathrm{RH}$ & $\mathrm{SD}$ \\
\hline ND2020 & 0.0786 & $1.46 \times 10^{-3}$ & 0.0930 & $2.57 \times 10^{-3}$ \\
NTBF2.5 & 0.0670 & $2.14 \times 10^{-3}$ & 0.0960 & $5.03 \times 10^{-3}$ \\
NTBF5 & 0.0687 & $5.60 \times 10^{-4}$ & 0.1150 & $4.57 \times 10^{-3}$ \\
NTBF10 & 0.0640 & $3.79 \times 10^{-4}$ & 0.1160 & $1.06 \times 10^{-3}$ \\
NTCF2.5 & 0.0443 & $2.27 \times 10^{-4}$ & 0.0700 & $5.77 \times 10^{-5}$ \\
NTCF5 & 0.0481 & $1.20 \times 10^{-4}$ & 0.1270 & $1.38 \times 10^{-3}$ \\
NTCF10 & 0.0335 & $1.96 \times 10^{-4}$ & 0.0890 & $1.69 \times 10^{-3}$ \\
NTHS2.5 & 0.0810 & $1.22 \times 10^{-3}$ & 0.1110 & $1.12 \times 10^{-2}$ \\
NTHS5 & 0.1080 & $3.47 \times 10^{-4}$ & 0.1590 & $7.65 \times 10^{-4}$ \\
NTHS10 & 0.0720 & $2.42 \times 10^{-4}$ & 0.0953 & $2.64 \times 10^{-3}$ \\
\hline
\end{tabular}

Publisher's Note Springer Nature remains neutral with regard to jurisdictional claims in published maps and institutional affiliations. 